\title{
Researching the Social Impact of the COVID-19 Pandemic on Students in Greece
}

\author{
K. Diamanti and S. M. Nikolaou
}

\begin{abstract}
The COVID-19 pandemic has dramatically changed the lives of people around the world, causing constraints, pressures, and deviations from habits as well as necessary survival activities. Its sweeping and leveling character has not left unaffected any part or any structure of our society, above all education. The lockdown and social alienation imposed on people as measures to stop the transmission of the disease has caused social, cognitive, and psychosomatic consequences, especially in the student world. This is not only because the learning process was initially interrupted and then replaced with distance education but also because students' social activity and social life changed radically. We consider in the present research the social impact of the pandemic as a benefit or a disadvantage in terms of students' social distancing, and their assessment of the difficulties and deprivations they experienced in order of precedence, as well as their views on dealing with the negative consequences of lockdown and social distancing. We aim to conduct a scientific discussion of the conclusions regarding the conditions created for young people in the context of lockdown and isolation and the views of young people on how to deal with the consequences of the pandemic.
\end{abstract}

Key words — COVID-19, Social Impact, Greek students.

\section{INTRODUCTION}

The outbreak of the COVID-19 pandemic and the consequences it has caused and continues to cause at every level of human life has led social scientists to analyze them from every perspective (social, political, economic, etc.). An important dimension is the impact of the sudden and rapid changes brought about by the pandemic on the everyday lives of people and particularly students and on the benefit or harm they understand to have been caused by the new conditions. Despite the social and educational conditions and the mandatory lockdown as a way of dealing with the pandemic, young people, especially students, evaluate from their own point of view both the living conditions in the family and the developments in the educational reality (distance education) and the shortcomings and deprivations they suffered. In the pilot research whose findings we present, students are invited to evaluate these conditions and to propose their own strategies for dealing with the negative consequences of all types of deprivation.

\section{THEORETICAL FramEWORK}

\section{A. The COVID-19 Pandemic and the Social Impact}

The advent of the new pandemic SARS-COV 2 or COVID-

Published on October 12, 2021.

K. Diamanti, University of Ioannina, Greece (e-mail: k.diamantir@uoi.gr),

S.-M.Nikolaou, University of Ioannina, Laboratory of Social Sciences and
19 established December 2019 as a new milestone in human history, confirming the sayings of scientists over the centuries that history repeats itself and pandemics overwhelm people every hundred years or so. The intensity and increased transmissibility of this new virus that has tainted thousands of lives is a special health-related situation which has quickly become a social status by tarnishing social structures [1] through its social impact.

Social impact refers to the collective and social benefit / harm produced by an activity or a consequence of a social, economic, environmental, or cultural phenomenon. It is difficult to advocate a specific method that will measure the social impact, however when we measure or evaluate the social impact of an action, we essentially evaluate the social results and the effects that result from the specific action. The social impact can be positive or negative. In the case of the COVID-19 pandemic, the social impact is assessed as having mostly negative elements.

Analyzing the collective social harm caused and being caused by the pandemic as a phenomenon with various dimensions, the first and decisive effect is the sudden restriction of the natural social role of the human being (Aristotle's man is a naturally social and political being). That restriction and essentially confinement at home, led, according to the surveys conducted so far, to a number of psychological, social and biological problems due to nonfulfillment of the need of "belonging" [2]. Confirmation of the significant effects of the pandemic on the psyches of people are also corroborated by Venkatesh \& Edirappuli [3] who focus on the presence of depression, anxiety, boredom, apathy or bad moods caused by the deprivation of personal freedom, changes in lifestyle and deprivation of loved ones. In fact, due to the seriousness of the situation, they suggest the direct support of the state for those who face extreme psychological issues through the creation of special centers and support lines. Furthermore, in the current social situation, it is considered appropriate for everyone to practice various sports or hobbies, to create virtual social gatherings and to follow a healthy diet as a psychosomatic aid and strategy to deal with the adverse effects of the COVID-19 pandemic in the short and long term.

A further dimension to the limitation of the social role of man is the "absence" of relationships, bonds, and social interactions necessary for the soul. The intense feeling of loneliness in these conditions has a bipolar dimension: a) emotional (individual) loneliness and $\mathrm{b}$ ) social loneliness and distancing by abstaining from any form of face-to-face communication and only socializing through social networks.

Education, Department of Primary Education, Faculty of Education, Greece (e-mail: snikola@uoi.gr) 
These two forms of loneliness cause people to feel fear, anger, boredom, and isolation. Friendships and social networks are largely based on the social activities in which a person is involved, and the more these are reduced, the more powerful social and individual loneliness is. Their lack and the isolation of the individual intensifies the feeling of loneliness and the absence of mental satisfaction. Research has shown that social networks are the most powerful factor in boosting self-confidence and self-esteem in times of crisis. In fact, certain social groups, such as students, at times when they felt lonely and sad, overcame these feelings by increasing their contacts with social networks. Loneliness is overcome either by personal introspection, or by resorting to virtual or social actions with mental feedback or with the support of a specialist. During the pandemic, lockdown and social distancing created difficulties in accessing ways to deal with alienation and loneliness, even introspection [4].

The social distancing and security measures imposed on everyone profoundly affected people's relationships with each other and even their feeling of "empathy" for their fellow man. According to Saladino et al. [5] widespread social upheaval has caused long-term and high-intensity anxiety, depression, and post-traumatic stress in many population groups. The stress not only of the infection itself but also of the contagion/transmission of the disease was and is a daily reminder of the importance of social distance and distancing.

The impact of the pandemic on humans seems to have left its mark strongly on human relationships. Without the particularity of empathy, the human elements of identifying with each other's problems, understanding, sense of closeness and non-distance have intensified social phobias and made human relationships more distant and impersonal [6].

On the other hand, the consequences of traumatic situations and images during the pandemic period (people daily facing death, illness, fear, etc.) have an impact on several areas of social reality [7]. Global human misery accompanies the new daily life of people, which bears no resemblance to life before the COVID-19 pandemic. The protagonist of socially distanced human life becomes "social pain" [8]. The large number of deaths that are announced on a daily basis also play an important role in the social impact of the pandemic, making the fear of disease transmission and possible death a major issue for people, along with the financial problems that arise and uncertainty about the future, elements that affect the sociability and psychology of people, something analogous to the impact of major natural disasters that occur in various parts of the world. The element that determines and significantly influences the social impact of the pandemic is "living at home", i.e., the measure of social isolation and distance from peers, friends, teachers, parents as it excludes social relationships from everyday life [9]. And all this in parallel with deep economic rifts and changes, unemployment, violence, inequalities, the crisis, the anxiety, the fear and the sadness. The stress and the extreme pressures generated across the extended social spectrum accelerate the presence of a trial profile of resistance and durability in people together with anxiety, sorrow, and denial of communication [10]. The distancing of man from any form of action of cultural, artistic and generally social interest causes the feeling of a fragile global social structure, which can collapse at any time [11]. The path of the challenge for a society called on to change has just begun [12]. And although it is a global phenomenon, it comes down to a local level, dealt with locally, as each society is individually called on to deal with the severity and intensity of the phenomenon [13].

The change in human behavior, in the conduct of social interaction is expected. Deprivation of liberty, alienation from loved ones and even a family living apart, feelings of helplessness and a general sense of an uncertain social future have exacerbated suicidal tendencies and behaviors in people in areas with high morbidity rates. Research by Orgiles et al. [14] found that children and young adults experienced many adverse symptoms due to the pandemic both emotionally and behaviorally, such as boredom, nervousness and anger, loneliness and various kinds of worries.

In fact, according to the Cartesian judgment of Quintili [15] the pandemic and its testing character "dissolves everywhere the inherent activity of Speech and forces the subjects to relapse into sad practices - mysticism, myths, prayers, prophecies, curses - like in the Middle Ages, when the plague decimated the lands. The pandemic is a special, complex, and major issue with "bad" interpretation but also "bad" management in a course determined by physical and socio-political factors.

\section{B. The COVID-19 pandemic and its impact on education}

The COVID-19 pandemic has caused a number of changes in society and education worldwide. No one involved in the educational process was properly prepared for the emergency need for distance learning. The new alternative plan for the restoration of educational activities requires cooperation, team spirit, a climate of solidarity and family support [16]. Digital learning is a fact, and an effort is being made to restore the lost ground of education using platforms, seminars, collaborative actions, and individual initiatives to improve learning interaction. In the new, subversive, different and demanding reality, negative emotions frame the learning situation whenever there are problems and difficulties of a technical nature, limited interaction, and communication from within all levels of education [17]. However, when problems are solved, students communicate and interact with their classmates and teachers and positive emotions emerge [18]. The search for educational support in order to keep learning at a high level becomes a matter of paramount importance [19].

According to Unesco [20], the effects of the sudden closure of schools are many. Among others are noted the suspension of the learning and development of the student, the uneven accessibility to learning by students of low socioeconomic strata and even the deprivation of the food they were given before the pandemic by the educational establishments, the lack of communication and cooperative interaction and the social isolation. An internet survey of the general population of China showed that the student body was more affected by quarantine than any other population group, with very strong signs and symptoms of anxiety and depression [21]. Students' needs for contact and interaction are more pronounced especially when studying in another city or in another country far away from their homeland. Loneliness, stress, and sadness are predominant elements of their daily lives and in fact all of them equate to a health risk similar to smoking, alcoholism 
and obesity. Social media play a significant role in the treatment of social withdrawal by facilitating the expression of their emotions and reducing the "cultural loneliness" [22]. Research also shows strong mood swings in students, mainly characteristised by feelings of anger and anxiety [23] particularly in the first phase of the pandemic in the spring of 2020 , intensifying their stress and anxiety about their studies. University institutions have put in place mechanisms for the restoration of higher education through digital technology using distance education and various learning platforms, as well as counseling by many institutions aimed at the psychological improving the psychology of students. Of course, this does not mean that the gaps created by the sudden suppression of any action and activity have been filled. What is certain is that students are adversely affected by sadness, anger, anxiety about the uncertainty of the educational continuity that prevails in the educational world but also loneliness, due to lack of physical communication and interaction with others [24]. But how do students who have experienced live learning and who have the experience of university socialization, assess the social impact of the pandemic?

\section{THE RESEARCH}

\section{A. Purpose and Methodology of the Research}

This research study aims to capture the social impact of the measures of lockdown and isolation due to the COVID-19 pandemic on young people and especially on students and the difficulties that arise on an individual-personal level.

In the research, the qualitative method is used as an appropriate method for describing and analyzing events by social subjects. Each subject constructs a unique description and analysis of events and through the qualitative method the subjective experience, the meaning, and the linguistic code of the subjects regarding the social events are highlighted [25]. The researcher maintains his objective and evaluative neutrality despite his personal beliefs, in order to understand the position of the subject [26].

In qualitative social research the purpose is focused on indepth investigation and recording of the views of individuals in the population. The aim is not to find a large and random sample, but the subjects are selected in a way that serves the purposes of the research [27]. The participants in the present study were selected based on their status as students in an urban area that offers both the possibilities of the activities available in a large city and the escape routes, e.g., in squares or out of town, without particular time restraints.

The research tool used to conduct the research is the interview, because it is a "social project" and not a simple collection of facts and data. In particular, the method of "qualitative interview" according to Burgess [28], or otherwise the semi-structured interview is characterized by freedom and flexibility, an informal style, a "theme-centered approach" and with research objectives that shape the questions, their content, and the way the researcher formulates them [29]. Semi-structured interviews have the ability to record the type and nature of the phenomenon being investigated, to listen to the inner thoughts of the subjects, unguided but moving freely, collecting data for evaluation
[30]. The research questions were designed to meet the criteria laid down [31] in order to provide reliable conclusions.

11 students (7 undergraduate and 4 postgraduate) participated in the research process, of which 6 were boys and 5 girls. The research was carried out at the end of June 2021, in the city of Ioannina, in Greece, during a period at the end of quarantine and compulsory lockdown at home with about $35 \%$ of the population having been fully vaccinated.

For the conduct of the research, an appropriate guide of semi-structured interview questions was divided into thematic areas [32], which was piloted on two students (one undergraduate and one postgraduate student) who were not included in the research participants. According to the interview guide, the researcher had the ability to possess the personal data of the respondents and their answers but used codes to protect their privacy. The codes contained a letter and a number in order to determine the academic level (in this case $\mathrm{S}=$ student $\mathrm{P}=$ postgraduate student.

The specific data collection was done in the physical space of the students, either with the use of social media due to the quarantine for COVID-19 or by recording or detailed transcribing of the answers, depending on the wish of the subjects [33]. During the interview the respondents were informed about the objectives of the research and the nature of the interview. The interview guide included questions about the social impact of distancing and home confinement, difficulties and deprivation, the impact on the family, distance education, gaps that may have been created and coping strategies to reduce the negative effects of social distancing.

Thematic units and subcategories were formed according to the separate topic each time. Thematic Content Analysis was used for data analysis, as it is a method of identifying and describing the issues arising from research data [34].

\section{B. Presentation of Results}

The transcripts of the interviews were categorized into subsections, which were provided by the research team or emerged during the analysis. The main sections were the extent of social distancing, the impact of social distancing, the difficulties that may have arisen, how the family was affected by social distancing, modern distance learning and the strategies for dealing with the negatives proposed by the research subjects for the effects of social distancing.

\section{1) Evaluation of the measures of social distancing}

Regarding the evaluation of the measures of social distancing and confinement at home, the majority of students, a percentage of $73 \%$, considered the measures positive for the reduction of the COVID-19 pandemic, while a percentage of $27 \%$ of the sample considered the measure negative.

Specifically S1 stated that "the measure of social distancing... was a necessary solution with positive results", $\mathrm{S} 2$ "was good for health reasons", S3" the measures did not help...the measures brought problems... we were very closed in", "it was an unpleasant choice for me but there was no other solution than the social distancing...", S7 "problems were created for the students... communication with the teachers was lost", the P1 "it was a necessary and positive preventive measure that limited the spread of the virus". While P2 "I cannot say good or bad under these 
conditions...distance and absence is not a positive thing ... but it is inevitable... it was necessary to reduce the virus".

\section{2) The impact of social distancing}

Regarding the question of the harm or benefit (impact) of lockdown and social distancing, in most of the answers discomfort and particular difficulty were pointed out with various problems, mainly of a psychological and social nature. Only three of the eleven subjects initially saw the lockdown as an opportunity to rest, but then over time realized the consequences of deprivation (mainly psychosomatic). For example:

"... It did not affect me because I found my friends in my student house... my daily life did not change”,

"...I retreated into myself, I did not see my friends... the impact was psychological”,

"... There was alienation due to circumstances... I had a feeling of distrust towards myself when I had a symptom of the virus",

"... The effects on me were psychological... there was a strong feeling of isolation and deprivation of liberty... I felt physically weak due to a depressed psychology",

"... In the first phase it had no impact, in the second phase it affected me for a long time because things were more dangerous"

"... It did not bother me at first... I found it an opportunity to rest in the summer, but I felt socially distant... it cost me psychologically".

\section{3) Difficulties and problems as a result of the pandemic}

The answers of the research subjects regarding the difficulties and problems that arose as a result of the pandemic showed diversity. Some believed that in the process they invented methods of communication and socialization, others that they encountered the problem of visiting their parents or living with their parents for many hours at home (space limitation). For two students, a very important aspect was the creation of fear and the constant anxiety about the spread of the disease. Also, a real problem that was pointed out was the lack of work for themselves and their parents and therefore the lack of money and the lack of financial support from the state. For example:

"... At first we all had difficulties but then we found new ways to have a better time... we were concerned with the issues of friendship and socialization"

"... I could not visit my parents" and "... difficulties at home with my parents... I wanted to do other things",

"... I had a feeling of fear of catching the virus",

" The difficulties did not appear at first... we thought everything would be solved quickly... but then I had a problem with studies... distance education... winter... bad weather, slow internet, but most importantly the difficulty of finding work, everything closed, the state not helping the unemployed with benefits and my parents receiving less money due to the suspension of work than employees would receive"

"... increased stress for fear of getting infected and passing something on to my family, difficulties with my master's degree",

“... It was very difficult for me in my studies... in accessing the library. I had to pay a courier to bring me the book I wanted to borrow after a week... also in my social and family relationships I did not see anyone."

\section{4) Social distancing and effects on the family}

Regarding the effects of the measures of social distancing on the family, the subjects' answers differed. For some, the lockdown led to the strengthening of family relations while for others it was a difficult situation of coexistence in the same space for many hours. For example:

"... my family and I got closer, we found our rhythms, we communicated more, we did activities together, like exercising",

"... the social distancing improved and helped our relationship more because we spent a lot of time together",

"... the family was very affected, my mom as self-employed had her shop closed, two siblings in one house, we did not know what to do, I felt like a bull in a China shop",

"... there were tensions... everyone locked in one place, psychological pressure... no personal space”,

\section{1) Remote modern learning and its problems}

The subjects of the research were $55 \%$ negative towards distance education, pointing out as the main reason its impersonal character and the lack of interpersonal communication.

“... At first, I did not like it at all... we did not see our company, our friends... cameras were closed, the lesson was not interesting",

"... I did not like it because in my school I wanted the labs",

"... I did not like it because it was an impersonal way of teaching”,

“... No, I did not like it... communication with staff was lost."

However, five of the six students pointed out in parallel with the negative elements of distancing, some positives that arose due to the conveniences of time and place.

"... I liked it because I did not have the anxiety of waking up to catch the bus... I just turned on the computer and connected to the lesson"

"... I liked it because I could take classes from the comfort of my own home."

"... very convenient for me the distance learning, also from a financial point of view........

"... I liked it... I was home... the teachers presented the material organized in slides",

"... I liked distance learning because I was at home with coffee."

\section{2) Deficiencies in distance learning}

The subjects of the research pointed out in their answers the elements that made distance education less functional than live teaching. The lack of personal contact, interpersonal relationships with teachers and university socialization prevailed.

"... I lacked a connection with the teacher... I lacked the communication - the immediacy",

"... I missed spending time with my classmates and the old way of teaching." 
"... I missed the immediacy and the visual contact, the essential communication of students with teachers, the magic of teaching and learning."

5) Methods - strategies to deal with minimizing the negative consequences of social distancing

Regarding the proposals of the research subjects for minimizing the negative effects of the pandemic, the answers focused on leisure activities before the pandemic and the help of experts for problems of a psychological nature.

"... do activities in recreation areas, find our friends in a normal life",

“...tighten our relationships, go out and be with our own people,"

"...start going out more with relatives, friends"

“... requires positive thinking and communication with friends and loved ones, engaging in activities, hobbies, reducing hours of watching $T V$ and negative news, vaccination is necessary",

"... choose maturity as individuals and as a society...do not forget human rights",

"...some who had severe problems such as depression who did not previously go to a mental health professional”.

\section{CONClusions-Discussion}

The COVID-19 pandemic and its impact appear to have caused changes and adverse effects on human communication, human relationships, and the quality of relationships. The daily coverage by the media of cases of patients in hospitals, and the daily increase in the mortality rate in various countries caused unprecedented emotional states, especially in young people. The creation of fear and the constant stress of illness caused intense psychological pressures that have even led to depression in many people [35].

Regarding the young people, students, in our research, the measures of social distancing and lockdown seem to have created difficulties, which are related to their socialization, relationships with family emotionally, materially, and financially but also to their education. More specifically, the measures of social distancing were considered by most to be necessary and positive for dealing with the possible spread of the virus, however, judging by the facts, they expressed the position that the confinement caused many problems. Assessing the impact of the measures of social distancing and isolation at home in terms of social outcomes and the effects that resulted, the research subjects identified serious shortcomings that caused daily difficulties. A significant shortcoming noted was the lack of live communication with friends which led to issues of deprivation of socialization, which caused even greater stress and fear of spreading the virus and disease but also deprivation of contact with parents or the extended family. Those students who lived with their parents had to face other kinds of problems. On the one hand, there was a constant concern that they might spread the virus themselves in the family environment, and on the other hand, there was the creation of emotional tensions from the many hours of coexistence in the same space, directly connected with the financial problems arising from compulsory closure of the parents' business or their "compulsory unemployment". However, there were cases where the family worked therapeutically in dealing with confinement and isolation. More free time gave them opportunities for cooperation (recreational and sports activities and educational games at home, common activities) and for strengthening relationships. It seems that families with strong emotional ties could cope better with the deprivation of social relationships, as the constructive use of free time acted as an antidote.

Coverage of study for young people in universities with distance education has highlighted in practice the problems of distance learning. More specifically, it emerged that distance education was a measure that ensured the possibility of contact of students with their status as students and with the cognitive objects of the faculties where they studied during this period but could in no way replace live teaching. The subjects of the research were students who had experienced live teaching before the pandemic. Therefore, they had the experience and based on the comparison of the two situations, it was found that their live teaching and life at the university as students were irreplaceable. More specifically, they pointed out as negative elements of their study with distance education the impersonal method of teaching, the lack of communication, directness and visual contact with the teacher, the lack of socialization and communication with fellow students. As they pointed out, "the magic of teaching and learning in live learning is irreplaceable."

The conditions created by the pandemic caused a social situation where the social distance between people dominated. Characteristic of man is his social nature. Where this is limited, problems arise, mainly psychosomatic. It is very important that the research subjects, in their proposals to minimize the negative effects of the pandemic, originally proposed the support of experts to solve psychological problems (depression, anxiety, fear, etc.). It is also very important to consider renewing and enhancing communication and the development of social relations afresh, by undertaking multiple activities that will further strengthen human, friendly or kinship relationships. Man should be strengthened by positive thinking, far away from negative news media showing ominous developments in the situation and creating social fears which make human relations more distant and impersonal, and with complete self-control and protection to create new communication networks that will not rely solely on digital media. Social activities with full participation and live communication, a socialized human condition must be strengthened in every way immediately, so that the conditions created by the pandemic are not consolidated and disrupt what is most characteristic of man: his social nature.

\section{REFERENCES}

[1] McMillen, Christian W. (2020). A brief introduction - Pandemics. Athens: Papadopoulos (in Greek).

[2] Lorreta, GY, Marango, T., \& Chitongo, L. (2020). The Impact of Social Distancing as a Response to COVID-19 among Foreign Students in Wuhan, China. Mankind Quarterly, 61 (2), 190-206.

[3] Venkatesh, A., \& Edirappuli, S. (2020). Social distancing in COVID19: what are the mental health implications? BMJ 2020; 369: m137.9. 
[4] Sawir, E., Marginson, S., Deumert, A., Nyland, C., \& Ramia, G. (2008). Loneliness and international students: An Australian study. Journal of studies in international education 12(2), 148-180.

[5] Saladino, V., Algeri, D., \& Auriemma, V. (2020). The psychological and social impact of Covid-19: new perspectives of well-being. Frontiers in Psychology 11, 2550.

[6] Saladino, V., Algeri, D., \& Auriemma, V. (2020). The psychological and social impact of Covid-19: new perspectives of well-being. Frontiers in Psychology 11, 2550.

[7] Piret, J., \& Boivin, G. (2020). Pandemics throughout history. Frontiers in microbiology, 11. [ https://doi.org/10.3389/fmicb.2020.631736]; Huremović, D. (2019). Brief history of pandemics (pandemics throughout history). Psychiatry of pandemics (pp. 7-35). Springer, Cham; Jones, DS (2020). History in a crisis - lessons for Covid-19. New England Journal of Medicine: 382 (18), 1681-1683; Komis, K. (2005). Cholera and Cleansers (19th-20th century). The example of Samiopoula. Ioannina, University of Ioannina (in Greek).

[8] Singh, J., \& Singh, J. (2020). COVID-19 and its impact on society. Electronic Research Journal of Social Sciences and Humanities 2, 168172.

[9] Osofsky, JD, Osofsky, HJ, \& Mamon, LY (2020). Psychological and social impact of COVID-19. Psychological Trauma: Theory, Research, Practice, and Policy, 12 (5), 468.

[10] Giavrimis, P. \& Nikolaou, S.-M. (2020). The Greek University Student's Social Capital during the COVID-19 Pandemic. European Journal of Education 7, (8), pp. 1-16.

[11] Bhattacharya, S. (2020). The Social Impact of the COVID-19 Pandemic. ORF Issue Brief No. 406, October 2020, Observer Research Foundation; Micheli, A. (2020). Culture in "restriction". The cultural experience of the imaginary and the real space. Social Research Review 154, 75-88.

[12] Dietrich, N., Kentheswaran, K., Ahmadi, A., Teychené, J., Bessière, Y., Alfenore, S., Laborie, S., Bastoul, D., Loubière, K., Guigui, C., Sperandio, M., Barna, L., Paul, E., Cabassud, C., Liné, A., \& Hébrard, G. (2020). Attempts, Successes, and Failures of Distance Learning in the Time of COVID-19. Journal of Chemical Education, August , 025. (available at: https://doi.org/10.1021/acs.jchemed.0c00717) (15.1.2021).

[13] Quintili, P. (2020). Niente di new sotto il sole. Dialogo on Covid-19. Castelvecchi Editor.

[14] Orgilés, M., Morales, A., Delvecchio, E., Mazzeschi, C., and Espada, J. (2020). Immediate psychological effects of the COVID-19 quarantine in youth from Italy and Spain. PsyArXiv 2020, 1-13. [doi: 10.1017 / s0033291720001841].

[15] Quintili, P. (2020). Niente di new sotto il sole. Dialogo on Covid-19. Castelvecchi Editor, p. 4-5.

[16] UNESCO: 290 Million Students Stay Home due to Coronavirus. (2020, March 7). Retrieved April 21, 2020, from learningenglish.voanews website: https://learningenglish.voanews.com/a/unesco-290-millionstudents-stay-home-due-to-coronavirus/5317148.html.

[17] Onyema, E. M., Eucheria, N. C., Obafemi, F. A., Sen, S., Atonye, F. G., Sharma, A., \& Alsayed, A. O. (2020). Impact of Coronavirus pandemic on education. Journal of Education and Practice, 11(13), $108-121$

[18] Giavrimis, P. \& Nikolaou, S.-M. (2020). The Greek University Student's Social Capital during the COVID-19 Pandemic. European Journal of Education 7, (8), pp. 1-16; Karalis, T., \& Raikou, N. (2020). Teaching at the times of COVID-19: Inferences and Implications for Higher Education Pedagogy. International Journal of Academic Research in Business and Social Sciences, 10 (5), 479-493.

[19] Daniel, J. (2020). Education and the COVID-19 pandemic. Prospects 49 (1), 91-96.

[20] UNESCO: 290 Million Students Stay Home due to Coronavirus. (2020, March 7). Retrieved April 21, 2020, from learningenglish.voanews website: https://learningenglish.voanews.com/a/unesco-290-millionstudents-stay-home-due-to-coronavirus $/ 5317148 . \mathrm{html}$

[21] Li, S., Wang, Y., Yang, Y., Lei, X., and Yang, Y. (2020). Analysis of influencing factors of anxiety and emotional disorders in children and adolescents during home isolation during the epidemic of novel coronavirus pneumonia. Chin. J. Child Heal 2020, 1-9; Saladino, V., Algeri, D., \& Auriemma, V. (2020). The psychological and social impact of Covid-19: new perspectives of well-being. Frontiers in Psychology 11,2550.

[22] Lorreta, GY, Marango, T., \& Chitongo, L. (2020). The Impact of Social Distancing as a Response to COVID-19 among Foreign Students in Wuhan, China. Mankind Quarterly, 61 (2), 190-206.

[23] Karasmanaki, E., \& Tsantopoulos, G. (2021). Impacts of social distancing during COVID-19 pandemic on the daily life of forestry students. Children and Youth Services Review, 120, 105781.
[24] Nikolaou, S.-M. (2020). The Effects on the Socio-Emotional State of Students in the National Exams in Greece from the Covid-19 Pandemic - Pilot Research. European Journal of Education, 3 (2), 1-8. Retrieved from http://journals.euser.org/index.php/ejed/article/view/4693.

[25] Tsiolis, G. (2010), The timeliness of the Biographical Approaches to Qualitative Social Research, in M. Pourkos, M. Dafermos, (ed.). Qualitative Research in Social Sciences: Epistemological, Methodological and Ethical Issues, pp. 347-370 Athens, Topos, (in greek).

[26] Strauss, A., \& Corbin, J. (1990). Basics of qualitative research. Sage publications, p. 48-54.

[27] Mantzoukas . F. (2007), Qualitative research in six easy steps. Epistemology, methods and presentation. Nursing 46 (1), 88-98; Iosisfidis, Th. (2003). Analysis of qualitative data in the Social Sciences. Athens: Critique.

[28] Mason, J., (2009). Qualitive Researching. Athens: Greek Letters (in Greek), p. 89; Burgess, RG (1984). In the Field: An Introduction to Field Research, London: Allen and Unwin, p. 102.

[29] Kerlinger, FN (1970). A social attitude scale: Evidence on reliability and validity. Psychological Reports, 26 (2), 379-383.

[30] Tsiolis, G. (2017). Thematic Analysis of Quality Data, Hellenic Open University.

[31] Mason, J., (2009). Qualitive Researching. Athens: Greek Letters (in Greek).

[32] Iosisfidis, Th. (2008 ). Qualitative research methods in the Social Sciences. Athens: Review.

[33] Robson, C., (2007). How to Do a Research Project: A Guide for Undergraduate Students. Oxford, UK: Blackwell Publishing.

[34] Tsiolis, G. (2017). Thematic Analysis of Quality Data, Hellenic Open University; Neuendorf, K.A. (2002). Defining content analysis. Content analysis guidebook. Thousand Oaks, CA: Sage.

[35] Saladino, V., Algeri, D., \& Auriemma, V. (2020). The psychological and social impact of Covid-19: new perspectives of well-being. Frontiers in Psychology 11, 2550.

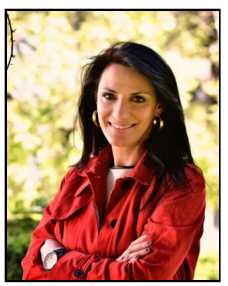

Konstantina Diamanti is a $\mathrm{PhD}$ candidate in the Sociology of Education at the Pedagogical Department of the University of Ioannina. She works as a researcher in the Laboratory of Social Sciences and Education.

She graduated from the Department of Philology of the University of Ioannina and she is a teacher of Philology in secondary education. She holds a Masters Degree in Education and Social Sciences from University of Frederick in Cyprus, specializing in Education.

She participated in two research projects at the University of Ioannina as a researcher - collaborator, from 2005-2009. She has worked as teacher in private education and at the Center for the Teaching of Greek Language and Culture to students at the University of Ioannina. Her research interests are related to social inequalities, social events that affect education, the Covid19 pandemic and its effects on education, etc.

Konstantina participates in conferences and has delivered papers and research findings, for example, her article "Distance Education in the Shadow of the Pandemic COVID-19" at the Proceedings of the Virtual International Academic Conference in Skopje.

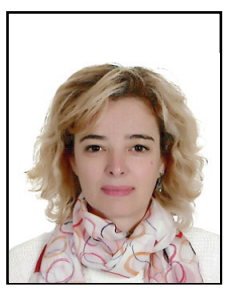

Sousanna -Maria Nikolaou, Associate Professor of Sociology of Education in the Department of Primary Education, University of Ioannina.

She has studied at the Department of Philosophy, Education and Psychology at the National University of Athens and she has Ph.D. in Philosophy and Social Pedagogy at the University of Cologne, Germany. She also has a degree of statutory interpreter (Greek German). She taught at the National University of Athens, at the Technological Educational Institute of Athens (Department of Early Childhood Education), and the Air Force Academy of Athens.

Research Interests: Sociology of education, Inequalities in education, Dropping out of compulsory education, Socialization of children, Childhood, Education and Mass Media, School Violence.

She has written monographs, chapters in collective volumes, articles in Greek and international journals with judges, has edited well-known collective volumes and has participate with contributions at Greek and international conferences. Indicatively, the following:

1. Nikolaou, S.-M. et al. (2020) (eds) Applied Qualitative Studies, Cambridge Scholars Publishing. 
2. Nikolaou, S.-M., et al. (2018) (eds), New Challenges in Education and Democracy: Sociological and Pedagogical Approaches to Democratic Education, Series: Sociology of Education, Athens: Gutenberg.

3. Nikolaou, S.-M. \& Barmparousis, Ch. (2017), Contemporary Sociological Issues. Social and Political Education with the Use of New Technologies, Athens: Gutenberg.

4. Nikolaou, S.-M., Papa, M., Gogou, L. (2018), Early school leaving in Greece and Europe and educational inequality. Actions and policies against educational and social exclusion, In: European Journal of Social Sciences Education and Research, Jan. Apr. 2018, Vol. 12, Nr. 1, pp. 229-236.

5. Nikolaou, S.-M., Papa, M. \& Gogou, L. (2018), Social inequalities in a time of economic crisis in Greece, In: International Journal of Social Science Research. Macrothink Institute, Vol. 6, No.1 March, pp. 61-75 (http://ijssr.macrothink.org).

From 2002 to present Associate Prof. Sousanna-Maria Nikolaou has participated in Organizing Scientific Committees of International and Hellenic Conferences, has been a supervisor of doctoral and postgraduate dissertations, Secretary of the Pedagogical Society of Greece, member of the Senate of the University of Ioannina (deputy) and member of the Laboratories of the Pedagogical Department of Primary Education of the University Ioannina. 